\title{
Commentary
}

\section{Experiences of Nurses Fighting Coronavirus Disease 2019 (COVID-19): A Qualitative Meta-Integration}

\author{
Manli Liu ${ }^{1}$, Ni Zhang ${ }^{2}$, Weiwei Wang ${ }^{2}$, Qingshan Chen $^{3}$, Weiju Chen ${ }^{1}$, Qingran Lin ${ }^{1}$, \\ ${ }^{1}$ The First Affiliated Hospital of Jinan University, Guangzhou, China \\ ${ }^{2}$ College of Nursing, Jinan University, Guangzhou, China \\ ${ }^{3}$ College of Pubic Hygiene, Jinan University, Guangzhou, China
}

\section{Email address:}

liumanli201004@163.com (Manli Liu), zhangniemail@126.com (Ni Zhang), qingranlin@126.com (Qingran Lin)

*Corresponding author

\section{To cite this article:}

Manli Liu, Ni Zhang, Weiwei Wang, Qingshan Chen, Weiju Chen, Qingran Lin. Experiences of Nurses Fighting Coronavirus Disease 2019 (COVID-19): A Qualitative Meta-Integration. American Journal of Nursing Science. Vol. 9, No. 6, 2020, pp. 394-401.

doi: 10.11648/j.ajns.20200906.11

Received: October 7, 2020; Accepted: October 20, 2020; Published: October 30, 2020

\begin{abstract}
Purpose: To systematically review the real experience of nurses in the fight against the coronavirus disease 2019 (COVID-19). Methods: PubMed, EMBASE, Cochrane Library, CBM, CNKI, Wan-Fang Data, and VIP from inception to April 2020. Qualitative research on real experience of nurses in the fight against the COVID-19 were collected. The study was screened by two researchers according to the criteria. After obtaining the data, the study quality was evaluated according to the JBI Critical Appraisal Tool, and the results were integrated by meta-synthesis. Results: Ten qualitative studies were included, involving 29 clear results and 7 categories, then 3 integrated themes were extracted: bear the burden of mind and body; desire for support and approval; self-worth is reflected. Conclusions: Nurses play an important role in the battle against the new coronavirus pneumonia, and nursing managers should dissolve the negative emotions of nurses in time. From the national and policy level, a scientific guarantee system should be formed for the materials, talent reserve, logistics, professional knowledge and other powerful guarantees. The community needs to foster a culture of respect for health care workers so that nurses can achieve their own value and gain a sense of professional identity and honor.
\end{abstract}

Keywords: COVID-19, Experience, Meta-synthesis Nurses, Qualitative Research

\section{Introduction}

Coronavirus disease 2019 (COVID-19) is an acute pneumonia caused by infection with the newly discovered $\beta$-coronavirus. The disease mainly manifests as fever, fatigue, and dry cough. The World Health Organization named the disease COVID-19. The disease is highly contagious and progresses rapidly, and the population is generally susceptible. Hospitals have become an important place to prevent and control COVID-19, and clinical first-line nurses have become the core force in the fight against COVID-19 [1]. Nurse's work experience in fighting the new coronary pneumonia epidemic can be useful when facing similar major emergencies in the future. At present, most of the nurses' work or psychological experience in combating COVID-19 is based on original research or description of the current situation. This study retrieves and integrates the qualitative research on the actual experience of clinical front-line nurses at home and abroad to combat COVID-19, systematically elaborate the clinical nurses' experience in the treatment of new coronary pneumonia, and summarize the key points that medical institutions and social organizations need to focus on in the future. Evidence-based nursing practice is needed in major public health emergencies.

\section{Information and Methods}

\subsection{Document Acceptance Criteria}

Inclusion criteria: (1) Research design included various 
types of qualitative research. (2) The research object was clinical nurses who participated in the treatment of new coronary pneumonia. (3) The phenomenon of interest was the real experience of clinical first-line nurses participating in the treatment of new coronary pneumonia. (4) The scene is that the clinical first-line nurses are at the treatment site of new coronary pneumonia.

Exclusion criteria: (1) The full text or documents with incomplete information cannot be obtained. (2) Only the literature of quantitative research. (3) Republished documents. (4) Literature evaluation quality is below B grade.

\subsection{Literature Retrieval Strategy}

PubMed, Cochrane Library, Embase, Chinese Biomedical Literature Database (CBM), China Knowledge Infrastructure
(CNKI), China Science and technology journal database (VIP), and Chinese Wanfang data were searched to collect qualitative research on the actual experience of clinical nurses in combating new coronary pneumonia. The search from inception to April 2020. In addition, the manual retrieval reference tracking method was used to ensure the comprehensiveness of the literature search [2]. The following search terms were used: "Novel coronavirus pneumonia", “COVID-19 virus", "Nurses", "rescue", "relief", "experience", "feeling", "qualitative research"; Chinese search terms were "new crown" "Virus pneumonia", "new coronavirus infection", "new coronary pneumonia", "nurse", "nursing", "rescue", "support", "combat", "experience"; the retrieval method was the combination of keywords and free words. Table 1 uses PubMed as an example of the retrieval strategy.

Table 1. PubMed Literature Search Strategy.

\begin{tabular}{|c|c|c|}
\hline Search & Query & Results \\
\hline \#1 & $\begin{array}{l}\text { Search ((nurs*[Title/Abstract]) OR (((((((((Nurse[Title/Abstract]) OR Personnel, Nursing[Title/Abstract]) OR Nursing } \\
\text { Personnel[Title/Abstract]) OR Registered Nurses[Title/Abstract]) OR Nurse, Registered[Title/Abstract]) OR Nurses } \\
\text { Registered[Title/Abstract]) OR Registered Nurse[Title/Abstract])) OR” Nurses”[Mesh])) }\end{array}$ & 488176 \\
\hline \#2 & $\begin{array}{l}\text { Search }(((((\text { Epidemic [Title/Abstract] }) \text { OR Epidemics [Mesh])) OR }((((((\text { Epidemic*[Title/Abstract]) OR Rescue [Title/Abstract] }) \\
\text { OR Assistance [Title/Abstract]) OR Relief [Title/Abstract]) OR Resist*[Title/Abstract]) OR Support [Title/Abstract]) }\end{array}$ & 2739638 \\
\hline \#3 & $\begin{array}{l}\text { Search }(((()(((()((\text { novel coronavirus pneumonia[Title/Abstract]) OR Wuhan coronavirus[Title/Abstract]) OR Wuhan seafood } \\
\text { market pneumonia virus[Title/Abstract]) OR COVID } 19 \text { virus[Title/Abstract]) OR COVID-19 virus[Title/Abstract]) OR } \\
\text { coronavirus disease } 2019 \text { virus[Title/Abstract]) OR SARS-CoV-2[Title/Abstract]) OR SARS2[Title/Abstract]) OR 2019-n } \\
\text { CoV[Title/Abstract]) OR } 2019 \text { novel coronavirus[Title/Abstract]) OR pneumonia*[Title/Abstract]) OR” severe acute respiratory } \\
\text { syndrome coronavirus 2"[Supplementary Concept] }\end{array}$ & 166699 \\
\hline \#4 & $\begin{array}{l}\text { Search }((((\text { Emotions"[Mesh]) OR }(((((\text { Emotion[Title/Abstract]) OR Regret[Title/Abstract]) OR Regrets[Title/Abstract]) OR } \\
\text { Feelings[Title/Abstract]) OR Feeling[Title/Abstract]) OR }((((\text { experience[Title/Abstract]]) OR interview[Title/Abstract]) OR } \\
\text { perspective*[Title/Abstract]) OR response[Title/Abstract]))) }\end{array}$ & 1305445 \\
\hline \#5 & Search (interview*[Title/Abstract] OR interviews [MeSH; no exp] OR experience*[Text Word] OR qualitative [Title/Abstract]) & 1454924 \\
\hline \#6 & Search (\# 1 and \# 2 and \# 3 and \# 4 and \#5) & 48 \\
\hline
\end{tabular}

\subsection{Literature Screening and Data Extraction}

Two researchers independently screened out the documents that met the requirements in accordance with the criteria for the acceptance of the documents. If there are disagreements during the screening process to discuss and resolve them, a third party was consulted to judge whether they are still inconsistent after consultation and discussion [3]. The content of data extraction included: author, year, country, qualitative research method, research object (sample size, age, working years, department), research content, main results (extracted topics).

\subsection{Quality Evaluation of Literature}

Two researchers (both have received training in evidence-based medicine courses) independently referred to the Australian JBI (Joanna Briggs Institute, JBI) Evidence-Based Health Care Center (2016) Qualitative Research Quality Evaluation Standards (JBI-QARI) [4]. The quality evaluation of the literature, the quality evaluation content was 10 items, and each item was evaluated with "yes", "no", "do not know", "not applicable", if it fully meets the quality evaluation standard, it is grade A, and partially meets the standard. Grades B and C were not satisfied at all [5]. In case of disagreement, the treatment method is the same as literature screening, and the quality evaluation grade of the studies included in this analysis was grade B and above.

\subsection{Literature Integration Method}

In this study, the Australian JBI evidence-based health care center's collective integration method [6] was used to integrate the literature results. After repeated reading, analysis, interpretation, and induction of the research results, the researchers regrouped into new categories, and finally integrated the summarized categories into new results.

\section{Results}

\subsection{Literature Search Results}

Four hundred eighty-five documents were retrieved through the database, and the reference document inclusion standards and quality evaluation standards are obtained. The number of documents finally obtained and included is 10 [7-16] articles. The literature search and screening process is shown in Figure 1. 


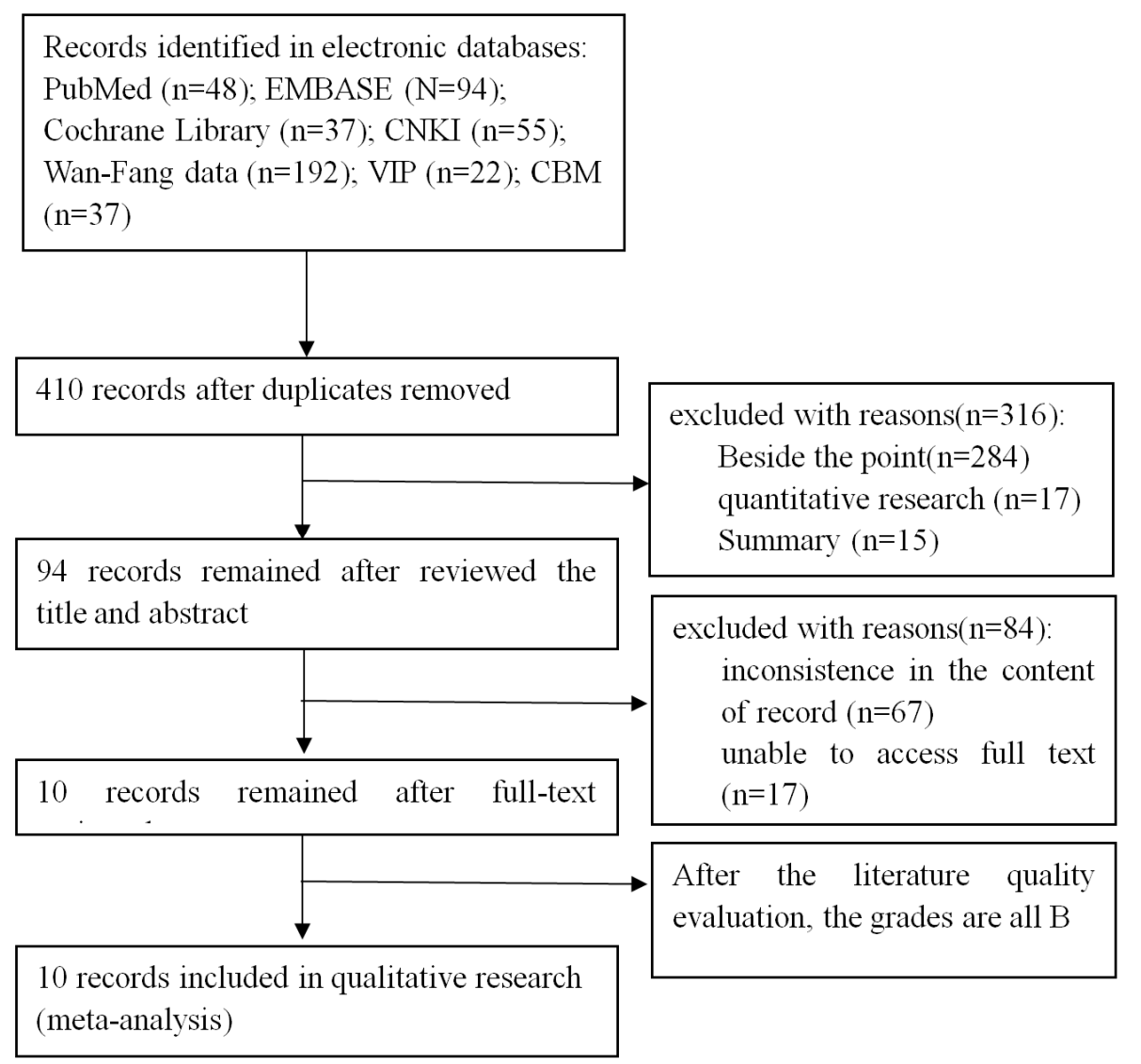

Figure 1. Shows flow chart of included/excluded studies.

\subsection{Basic Characteristics and Quality Evaluation of Included Studies}

The basic characteristics of the included literature are shown in Table 2, and the quality evaluation results of the included literature are shown in Table 3.

Table 2. Characteristics of included studies.

\begin{tabular}{|c|c|c|c|c|c|c|c|c|}
\hline \multirow{2}{*}{ Author } & \multirow{2}{*}{ Country } & \multirow{2}{*}{ Study type } & \multicolumn{4}{|c|}{ Research object } & \multirow{2}{*}{ Content } & \multirow{2}{*}{ Result } \\
\hline & & & Sample & Age & Working age & Dept & & \\
\hline $\begin{array}{l}\text { Zhou Y et al } \\
{[7]}\end{array}$ & China & $\begin{array}{l}\text { Phenomenological study, } \\
\text { semi-structured interview }\end{array}$ & 7 & $\geq 26 y$ & $2-21 y$ & $\begin{array}{l}\text { Outpatient Dept, } \\
\text { Infection Dept }\end{array}$ & real experience & 3 themes \\
\hline $\begin{array}{l}\text { Liu HY et al } \\
{[8]}\end{array}$ & China & $\begin{array}{l}\text { phenomenological study, deep } \\
\text { interview, group interview }\end{array}$ & 15 & $28-45 y$ & $8-24 y$ & RICU & $\begin{array}{l}\text { psychological } \\
\text { stress response }\end{array}$ & 3 themes \\
\hline $\begin{array}{l}\text { Liu L et al } \\
\text { [9] }\end{array}$ & China & $\begin{array}{l}\text { phenomenological study, } \\
\text { semi-structured interview }\end{array}$ & 10 & $28-45 y$ & - & RICU, Infection Dept & care experience & 3 themes \\
\hline $\begin{array}{l}\text { Yang HH et } \\
\text { al [10] }\end{array}$ & China & $\begin{array}{l}\text { phenomenological study, } \\
\text { semi-structured interview }\end{array}$ & 10 & $22-32 y$ & $3-10 y$ & - & real experience & 3 themes \\
\hline $\begin{array}{l}\text { Ge J et al } \\
{[11]}\end{array}$ & China & $\begin{array}{l}\text { phenomenological study, } \\
\text { semi-structured interview, } \\
\text { deep interview }\end{array}$ & 13 & $25-45 y$ & $1-27 y$ & Pneumology Dept & work experience & 3 themes \\
\hline $\begin{array}{l}\text { Li GL et al } \\
{[12]}\end{array}$ & China & phenomenological study & 15 & $24-41 y$ & $2-23 y$ & $\begin{array}{l}\text { Pneumology Dept, ED, } \\
\text { Infection Dept, ICU }\end{array}$ & $\begin{array}{l}\text { body and mind } \\
\text { experience }\end{array}$ & 5 themes \\
\hline $\begin{array}{l}\text { Qu X et al } \\
{[13]}\end{array}$ & China & phenomenological study & 8 & $22-43 y$ & - & - & $\begin{array}{l}\text { treatment } \\
\text { experience }\end{array}$ & 3 themes \\
\hline $\begin{array}{l}\text { Tu WY et al } \\
{[14]}\end{array}$ & China & $\begin{array}{l}\text { phenomenological study, } \\
\text { semi- } 16 \text { structured interview, } \\
\text { deep interview }\end{array}$ & 10 & $27-46 y$ & - & Isolation ward & work experience & 7 themes \\
\hline $\begin{array}{l}\text { Guo HY et } \\
\mathrm{al}[15]\end{array}$ & China & $\begin{array}{l}\text { phenomenological study, } \\
\text { semi-structured interview }\end{array}$ & 15 & $22-43 y$ & $1-14 y$ & ICU & work experience & 8 themes \\
\hline $\begin{array}{l}\text { Liu TE et al } \\
{[16]}\end{array}$ & China & $\begin{array}{l}\text { phenomenological study, } \\
\text { semi-structured interview }\end{array}$ & 10 & $25-36 y$ & $2-15 y$ & - & $\begin{array}{l}\text { psychological } \\
\text { experience }\end{array}$ & 3 themes \\
\hline
\end{tabular}

Note: -, no record; Dept, department; RICU, respiratory intensive care unit; ED, emergency department; ICU, intensive care unit; y, years. 
Table 3. Include studies quality evaluation.

\begin{tabular}{|c|c|c|c|c|c|c|c|c|c|c|}
\hline $\begin{array}{l}\text { Qualitative research evaluation } \\
\text { standard }\end{array}$ & $\begin{array}{l}\text { Zhou Y } \\
\text { et al [7] }\end{array}$ & $\begin{array}{l}\text { Liu HY } \\
\text { et al }[8]\end{array}$ & $\begin{array}{l}\text { Liu L } \\
\text { et al [9] }\end{array}$ & $\begin{array}{l}\text { Yang HH } \\
\text { et al [10] }\end{array}$ & $\begin{array}{l}\text { Ge J } \\
\text { et al [11] }\end{array}$ & $\begin{array}{l}\text { Li GL et } \\
\text { al [12] }\end{array}$ & $\begin{array}{l}\text { Qu X et } \\
\text { al [13] }\end{array}$ & $\begin{array}{l}\text { Tu WY } \\
\text { et al }[14]\end{array}$ & $\begin{array}{l}\text { Guo HY } \\
\text { et al [15] }\end{array}$ & $\begin{array}{l}\text { Liu TE } \\
\text { et al [16] }\end{array}$ \\
\hline $\begin{array}{l}\text { 1. 1. Is there congruity between the } \\
\text { stated philosophical perspective and the } \\
\text { research methodology? }\end{array}$ & - & $\mathrm{Y}$ & - & - & - & 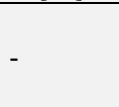 & - & - & - & - \\
\hline $\begin{array}{l}\text { 2. Is there congruity between the } \\
\text { research methodology and the research } \\
\text { question or objectives? }\end{array}$ & $\mathrm{Y}$ & $\mathrm{Y}$ & Y & $\mathrm{Y}$ & $\mathrm{Y}$ & $\mathrm{Y}$ & Y & Y & $\mathrm{Y}$ & $\mathrm{Y}$ \\
\hline $\begin{array}{l}\text { 3. Is there congruity between the } \\
\text { research methodology and the methods } \\
\text { used to collect data? }\end{array}$ & $\mathrm{Y}$ & $\mathrm{Y}$ & $\mathrm{Y}$ & $\mathrm{Y}$ & $\mathrm{Y}$ & $\mathrm{N}$ & $\mathrm{Y}$ & Y & $\mathrm{Y}$ & $\mathrm{Y}$ \\
\hline $\begin{array}{l}\text { 4. Is there congruity between the } \\
\text { research methodology and the } \\
\text { representation and analysis of data? }\end{array}$ & Y & $\mathrm{Y}$ & $\mathrm{Y}$ & $\mathrm{Y}$ & $\mathrm{Y}$ & $\mathrm{Y}$ & $\mathrm{Y}$ & Y & $\mathrm{Y}$ & $\mathrm{Y}$ \\
\hline $\begin{array}{l}\text { 5. Is there congruity between the } \\
\text { research methodology and the } \\
\text { interpretation of results? }\end{array}$ & Y & $\mathrm{Y}$ & $\mathrm{Y}$ & $\mathrm{Y}$ & $\mathrm{Y}$ & $\mathrm{Y}$ & $\mathrm{Y}$ & Y & $\mathrm{Y}$ & $\mathrm{Y}$ \\
\hline $\begin{array}{l}\text { 6. Is there a statement locating the } \\
\text { researcher culturally or theoretically? }\end{array}$ & $\mathrm{N}$ & $\mathrm{N}$ & $\mathrm{N}$ & $\mathrm{N}$ & $\mathrm{N}$ & $\mathrm{N}$ & $\mathrm{N}$ & $\mathrm{N}$ & $\mathrm{Y}$ & $\mathrm{N}$ \\
\hline $\begin{array}{l}\text { 7. Is the influence of the researcher on } \\
\text { the research, and vice- versa, } \\
\text { addressed? }\end{array}$ & $\mathrm{N}$ & $\mathrm{N}$ & $\mathrm{N}$ & $\mathrm{N}$ & $\mathrm{N}$ & $\mathrm{N}$ & $\mathrm{N}$ & $\mathrm{N}$ & $\mathrm{N}$ & $\mathrm{N}$ \\
\hline $\begin{array}{l}\text { 8. Are participants, and their voices, } \\
\text { adequately represented? }\end{array}$ & $\mathrm{Y}$ & $\mathrm{Y}$ & $\mathrm{Y}$ & $\mathrm{Y}$ & $\mathrm{Y}$ & $\mathrm{Y}$ & $\mathrm{N}$ & Y & $\mathrm{Y}$ & $\mathrm{Y}$ \\
\hline $\begin{array}{l}\text { 9. Is the research ethical according to } \\
\text { current criteria or, for recent studies, } \\
\text { and is there evidence of ethical } \\
\text { approval by an appropriate body? }\end{array}$ & $\mathrm{Y}$ & $\mathrm{Y}$ & $\mathrm{Y}$ & $Y$ & $\mathrm{Y}$ & $Y$ & $\mathrm{Y}$ & $\mathrm{Y}$ & $\mathrm{Y}$ & $\mathrm{Y}$ \\
\hline $\begin{array}{l}\text { 10. Do the conclusions drawn in the } \\
\text { research report flow from the analysis, } \\
\text { or interpretation, of the data? }\end{array}$ & $\mathrm{Y}$ & $\mathrm{Y}$ & $Y$ & $Y$ & $\mathrm{Y}$ & $\mathrm{Y}$ & Y & Y & $\mathrm{Y}$ & $\mathrm{Y}$ \\
\hline Study quality & $\mathrm{B}$ & $\mathrm{B}$ & $\mathrm{B}$ & $\mathrm{B}$ & $\mathrm{B}$ & $\mathrm{B}$ & $\mathrm{B}$ & $\mathrm{B}$ & $\mathrm{B}$ & $\mathrm{B}$ \\
\hline
\end{tabular}

Note: -, no record; Y, yes; N, no.

\subsection{Meta Integration Results}

The researchers extracted 29 research topics from the 10 articles included, and after summarizing similar research results, they formed 7 categories and integrated them into 3 integrated results.

\subsubsection{Integration Result 1: Bear the Burden of Body and Mind}

Nursing staff not only face psychological emotions such as tension and anxiety during major public health emergencies, but also suffer from physical fatigue such as heavy workload [17].

\section{Category 1: More nervous and anxious}

The sudden occurrence of the epidemic makes it difficult for the clinical nurses who have penetrated the front-line to prepare for adequate psychological preparation, and the psychological problems are more significant [18]. At the beginning of the appear of COVID-19, nurses lacked awareness and experience of the disease and developed feelings of worry, fear, etc. (“... contacting a large number of patients every day, very worried about being infected [11]; after suffering from patients coughing, sputum spray, fear of being infected" [8]). Insufficient supply of protective materials made the nurses anxious ("I just started in the fever isolation ward... very insecure" [7]). The rise in the number of confirmed cases, the complex condition, has caused the nurses to be nervous and insomnia (“... It is difficult to keep up with the rhythm, often insomnia, and feel frustrated" [13]). Worried about their infection and infection to their families ("learned this when the disease is very contagious, I am also afraid of being infected" [16]; "Worried about being infected and even more afraid of transmitting it to my family..." [15]). I can't take care of my family and feel guilty ("My daughter is only 2 years old. It is when you need to be accompanied... I feel sorry for the child" [11]).

\section{Category 2: Large workload}

The increase in workload and changes in the working environment also pose a considerable challenge to the nurse's ability to withstand the disease. The rapid development of the disease and the lack of human resources have led to an increase in the workload of the nurse ("This disease is sudden, we have insufficient staff” [7]; "After the rescue work, a large number of fever patients flooded into the hospital" [8]). Because of the special disease, nurses have to play multiple roles at the same time (“... we are responsible for everything needed by patients such as diet, treatment, inspection, basic care" [10]), and heavy protective clothing also gives nurses who were working at full capacity. This increased the burden ("After wearing these three layers... the whole body is not breathable, the goggles will also fog, which seriously affects our performance" [9]; "This protective equipment makes me prone to hypoxia..." [14]). 


\subsubsection{Integration Result 2: Longing for Support and Recognition}

The epidemic rescue is a systematic work that requires the assistance of multiple departments and professions and the support of multiple teams $[19,20]$. To charge the clinical nurses to fight the epidemic on the front line requires not only the collaboration of multiple departments, but also the eagerness to get support and recognition from all quarters. The support of all aspects allows the nurses to strengthen their belief in fighting the epidemic.

Category 1: Understanding of patients and their families

Nurses are the people who have the most contact with patients and their families, and they are most eager to get their understanding and support ("wearing tightly wrapped protective clothing and goggles... the puncture is unsuccessful, and they are afraid that the patient will blame" [13]). In the early stage, patients and their families experienced panic, coupled with the lack of medical resources, and some patients and their families transferred conflicts to the nurses ("because... patients have poor medical experience, they will vent their anger to the medical staff" [13]; "patients feel there is a lot of pressure, and there is a tendency to lose temper with medical staff" [10]). Some patients even resort to verbal violence ("... cannot overcome the epidemic or ineffective treatment, please take the initiative to admit your mistakes and ask for forgiveness!" [8]). However, the understanding and approval of the patients and their families also made the nurses feel warm ("We all wear protective clothing... but there are always patients who want to know our name, ask which hospital I came from, and say 'thank you very much"” [15]).

\section{Category 2: Team and organizational support}

Adequate protective materials and logistical support can eliminate nurses' worries (“... some protective equipment stocks can't last a few days. I hope to be able to match the protective equipment items" [9]; "Now medical supplies are too precious... we use it and cherish it all" [11]). Systematic and comprehensive knowledge training can eliminate the fear of nurses ("The first time to participate in such epidemic treatment... I hope to be able to fully train [10]; I almost forgot to put on and take off isolation clothes..." [7]). The friendly team and family organization make the nurses feel empowered ("Our group works very well... Every day, we discuss coping strategies or work precautions" [11]; "My parents and lovers always say that let me work at ease..." [10]).

Category 3: Social group support

The support of social resources has solved the urgent needs of nurses, so that they can focus more on the first-line treatment, and the powerful logistics team and socially conscious people have solved the diet and accommodation problems for them ("10 pm... also sent us food. I feel like living in a big warm family" [10]; "Different diets between the North and the South... with foods that conform to the dietary habits of the northerners" [9]) and more intimate contributions from volunteers (“... preparation of delicious meals, nursing shoes and cold-proof vests... we are deeply moved by their dedication" [15]).

\subsubsection{Integration Result 3: Self-worth Is Reflected \\ Category 1: Acquiring knowledge and skills}

COVID-19 is a brand-new disease. Nurses who are on the front line against the epidemic not only participated in the whole process of nursing this disease, but also gained new knowledge and experiences ("I have completed... hemodialysis treatment, lamenting his unlimited potential" [15]; “... we collect protection and nursing skills every day... I feel that I am becoming more and more professional in this area of nursing" [14]), which also enhances the nurse's ability to overcome the COVID-19 epidemic ("After participating in the training of new coronary pneumonia prevention knowledge, I have confidence in knowing each other and fighting alongside each other" [12]; “... There are many things worth learning from colleagues in different hospitals... I believe this battle will be quickly controlled." [15]).

Category 2: Get a sense of accomplishment

The nurse saw the pain of the patient disappeared after her careful care, and was recognized by the patient, making the nurse proud of her profession ("Whenever I see a cured patient discharged from the hospital, I am very relieved... the work is more energetic."[11]; "We are very proud of seeing the patient cured and discharged" [10]; "Seeing the patient's breathing stable... an inexplicable feeling of accomplishment"[14]).

Category 3: Gain a sense of honor

The honor of the nurse comes from the protection of life. This time, the majority of nursing workers in the new coronary pneumonia epidemic have received attention and recognition from all walks of life. They have expressed their affirmation and praise for the medical staff's work day and night, and their excellent technology ("Get encouragement from family, friends, colleagues and even strangers" [15]; “... Recalling the scene when everyone read the oath of medical students when they graduated. Now I support the front line, and my heart is full of pride and pride" [13]; “... Fighting here in times of crisis is a mission in itself, which is a unique sense of mission belonging to medical staff" [16]).

\section{Discussion}

The nursing staff is an important part of the medical system, and it is even more important in the context of a major public health emergency, such as new coronary pneumonia. From the perspective of the medical teams sent to support Hubei, the proportion of nursing staff was also significantly higher [19, $21,22]$. In this study, the meta-integration of the included qualitative research was conducted to discuss the problems arising from the clinical first-line nurses' fight against COVID-19 and the areas that require attention when similar major public health emergencies occur in the future.

\subsection{Caring About the Physical and Mental State of the Nurse and Improving the Level of Humanized Management}

The results of this meta-integrated study show that the psychological and physiological problems of clinical first-line nurses in the fight against COVID-19 are more prominent. At 
the beginning of the COVID-19, clinical first-line nurses tended to experience negative emotions, such as tension and anxiety. Studies have shown [23] that the changes experienced by nurses from negative emotions to positive emotions under major public health emergencies are conducive to reducing the stress response of medical staff. Therefore, organization managers should pay attention to the changes of nurses' mental state in a timely manner, actively listen and comfort, arrange appropriate rest, introduce psychological counselors, etc. to help them resolve their negative emotions. The nurse group takes women as the main body [24]. The physiological endurance and the particularity of the physiological cycle, coupled with the heavy protective clothing, the increase in workload, and the long-term shifting, determine that the management should be based on the actual situation from a humanized perspective. The workload of each front-line nurse should be assessed scientifically, with flexible scheduling and arrangement of vacations according to the physical condition of the nurse; during non-epidemic situations, programs should also be formulated to strengthen training and enhance the nurse's mental and physical qualities. Nurses can calmly face major public health emergencies again. Research shows [17] that weak psychological and physical qualities not only hinder the smooth progress of rescue work, but also cause harm to the nurses themselves.

\subsection{Pay Attention to the Needs of Nurses and Increase the Support of Hospitals and Society}

To effectively prevent and control the new coronary pneumonia epidemic, the safety of patients and their families must be ensured by taking isolation measures such as avoidance of visits [25], patients and families should understand the epidemic prevention and control isolation measures, support nurses, patients, and family. Support and affirmation make the nurse feel more powerful and confident in defeating the epidemic [26]. Nurses work on the front lines of the epidemic, and strong support are the foundation of their dedicated work [1]. The hospital organization should optimize the material management process according to the specific situation, do a good job in material resources and logistics support, and form a scientific material management system. Sudden occur of the epidemic, shortage of nursing staff, lack of knowledge of the disease, and lack of specialist nursing measures and protective knowledge have hindered the smooth progress of nurses' work and also increased the psychological pressure of nurses [27]. Daily work should be strengthened for clinical front-line nurses by public health incident prevention and control training, organizing and implementing simulation drills, formulating relevant management processes and emergency plans, in case of unexpected needs. When the epidemic situation occurs, according to the different nurses' working departments and the needs of the nurses themselves, the specialized knowledge training should be strengthened to deal with the epidemic. Adequate knowledge reserve is not only the guarantee for patients to get good care, but also the basis for nurses to eliminate fear and protect themselves. Studies have shown [28] that the strong support of social groups can significantly enhance the willingness of nurses to participate in rescue. From the results of this meta-integration study, the support of social groups allows nurses to multiply their confidence in rescue, so they must call for greater publicity efforts to raise awareness of nursing work, and effectively guide patients, family members, and the public to recognize the value of nursing work in the treatment of epidemic situations.

\subsection{Self-worth Is Reflected}

The realization of the self-worth of nurses often comes from the sense of honor brought by life-saving treatment [29]. From the perspective of this meta integration, nurses who joined the front line of anti-epidemic was expressed unprecedented pride and identity. The satisfaction of acquiring new knowledge and skills, the recognition and praise of the cured patients, the media reports, and the support of the whole country, highlights that their self-worth hope is recognized, and the respected psychology is satisfied. With the development of nursing education, nurses also have higher expectations for their professional development. Medical institutions should provide nurses with more learning opportunities and formulate scientific promotion paths and diversified development paths, improving salary and development. This should start with respect to space, practice environment, social status, etc., care for the physical and mental health of the medical staff, creating a good atmosphere for the whole society to respect medical care, and enhancing the professional honor of medical staff through various forms, so that nurses can promote their specialties while realizing their own value. The development of nurses and the development of high-quality nursing clinical practice.

\section{Conclusion}

Nurses play a vital role in the fight against new coronary pneumonia. Nursing managers must resolve the physical and mental burdens of nurses in a timely manner. From the national and policy levels, a scientific support system should be formed for materials, talent reserves, logistics, professional knowledge, and other strong guarantees. The whole society should create an atmosphere of respect for medical care, so that nurses can realize their own values in multiple ways and gain a sense of professional identity and honor.

\section{Limitation}

Due to factors, such as age, years of employment, professional title, department, and other factors, the subjective experience of nurses in the care of patients with new coronary pneumonia may be different. It is recommended to conduct a qualitative research and analysis on nurses' years of employment, age, and professional titles in the future.

\section{Author Contributions}

Manli Liu and Ni Zhang are co-first authors. 


\section{Conflict of Interest}

All the authors do not have any possible conflicts of interest.

\section{Acknowledgements}

Thanks to all participants in this article.

\section{References}

[1] Xu MC, Zhang Y. Psychological status survey of first clinical first-line support nurses fighting against pneumonia caused by a 2019 novel coronavirus infection [J]. Chinese Nursing Research, 2020, 34 (03): 368-370.

[2] Liu J, Mi YY. Psychological experiences of Chinese kidney transplant recipients: a meta-synthesis of qualitative studies [J]. Journal of Nursing Science, 2019, 34 (04): 79-82.

[3] Zhou HL, Yang XY, Pan XP, Lu WX, et al. Disease Burden of Diabetes Mellitus in Chinese Population: A Systematic Review [J]. Chinese Journal of Evidence-Based Medicine, 2014, 14 (12): 1442-1449.

[4] Hu Y. Evidence-base nursing [M]. Beijing People's Medical Publishing House. 2018: 157-163.

[5] Wang LF, Mi YY, Jin J, Zhang JC, Li RM, et al. The experience and coping behaviors of work stress among ICU nurses: a meta-synthesis of qualitative studies [J]. Chinese Journal of Nursing, 2019, 54 (10): 1566-1571.

[6] Lockwood C, Munn Z, Porritt K. Qualitative research synthesis: methodological guidance for systematic reviewers utilizing meta-aggregation [J]. Int J Evid Based Health, 2015, 13 (3): 179-187.

[7] Zhou Y, Jing T, Chen XQ, Zhen ZH. Qualitative study on the work pressure of first-line nurses in the children's hospital against new coronavirus pneumonia [J]. Journal of Nursing and Rehabilitation, 2020, 19 (2): 66-69.

[8] Liu HY, Zhen BF, Yang YF, Jiang Q, Lu WJ. Qualitative Study on Psychological Stress of Rescue Nurses in New Coronavirus Pneumonia Epidemic Area $[\mathrm{J}]$. Chinese General Practice Nursing, 2020, 18 (7): 49-51.

[9] Liu L, Zhang JD, Ma SS, Xu HM, Chen XL, et al. A qualitative study on the nursing experience of first-line nurses assisting Hubei against new coronary pneumonia [J]. Journal of Qilu Nursing, 2020, 26 (04): 3-6.

[10] Yang HH, Dai L, Chen QX, Liu GZ. A qualitative study on the psychological stress of first-line nurses in primary hospitals who participated in the fight against novel coronavirus pneumonia [J]. Journal of Nursing Administration: 2020. 20 (2): $1-4$.

[11] Ge J, Meng JN. Work experience among supporting nurses from Guangdong province during the epidemic of Coronavirus Disease 2019: a qualitative study [J]. Journal of Nursing Science, 2020: 1-3.

[12] Li GL, Zhang QH, Fan JJ, et al. Qualitative study on the physical and mental experience of clinical first-line nurses in the prevention and control of new coronavirus pneumonia $[\mathrm{J}]$, Chinese General Practice Nursing, 2020, 18 (6): 59-63.
[13] Qu X, Zhang L, Zhang P, Hu WT, et al. Qualitative research on treatment experience among front-line nurses fighting against corona virus disease 2019 [J]. Chinese Nursing Research, 2020, 34 (05): 759-761.

[14] Tu WY, Lin SK, Zhen XM, Xie QL. Qualitative study of ICU nurses participating in the treatment of patients with severe coronavirus [J]. Chinese Nursing Research, 2020: 1-5.

[15] Guo HL, Song CY, Wang GL, Huang HY, Liu YL. Qualitative study of work experience of support nurses in isolation unit for patients with severe COVID-19 [J]. Chinese Nursing Research, 2020, 34 (06): 934-937.

[16] Liu YE, Zhai ZC, Hu DY, Li M, Yang LJ, et al. A qualitative study on the psychological experience of frontline support nurses in the fight against new coronavirus pneumonia [J]. Chinese Journal of Modern Nursing, 2020, 26. E001-E001.

[17] Wu F, Sheng Y, Zhang YJ, Zhu LL, Liu XH. Qualitative Study on Rescue Experience of Nurses in Disaster Response: A Meta Synthesis [J]. Journal of Nursing (China), 2019, 26 (03): 28-33.

[18] Zhang LM, Bi YY, Yang XQ, Gao Y. Study on the Factors Affecting Psychological Health of the Nurses in the Period of SARS Outbreak [J]. Chinese Journal of Modern Nursing, 2005 (08): 580-582.

[19] Lam S K K, Kwong E W Y, Hung M S Y, et al. Nurses' preparedness for infectious disease outbreaks: A literature review and narrative synthesis of qualitative evidence [J], 2018, 27 (7-8): e1244-e1255.

[20] Chen G. Self-psychological adjustment and psychological crisis intervention strategies for disaster rescue nurses [J]. Chinese Nursing Management, 2018, 18 (07): 888-894.

[21] Li YL, Li F, Shi DL, et al. The research progress of disaster nursing in China $[\mathrm{J}]$. Chinese Nursing Management, 2015, 15 (01): 115-118.

[22] 105 people went to Wuhan, Henan Province, the eighth batch of aid medical team in Hubei set off [EB/OL], (2020.02.15) [2020.02.28]. http://henan.people.com.cn/n2/2020/0215/c351638-33798986. html.

[23] Feng J, Yang J. Discussion on Medical Personnel' s Emotion Changes under the Sudden Public Health Accident [J]. Journal of Nursing Administration, 2004 (04): 373-374.

[24] He Y, Zhou YH, Hou AH. The impact of organizational climate and psychological empowerment on nurses' job burnout [J]. Journal of Nursing Administration, 2015, 15 (10): 685-688.

[25] Zeng JF, Cai HT, Zou CM. Psychiatric emergency nursing management for the prevention of 2019 new coronavirus infection [J]. Chinese General Practice Nursing, 2020, 18 (04): 419-421.

[26] Huang JY, Ying WJ, Huang HL, et al. Relationship Between Depression Status and Working Pressure of Nurses in the Emergency Department [J]. Journal of Nursing Science, 2003 (12): 887-889.

[27] Qian XY, Xie XE, Wang YY, Ju LL, Gu P, et al. Qualitative research in the real experiences in the treatment of patients with new respiratory infectious disease $[\mathrm{J}]$. Modern Clinical Nursing, 2016, 15 (08): 15-19. 
[28] Qureshi K, Gershon RR, Sherman M F, et al. Health care workers' ability and willingness to report to duty during catastrophic disasters [J]. J Urban Health, 2005, 82 (3): 378-388.
[29] Liu QQ, Li RQ, Geng XW. Survey of status quo of nurses' cognition level and attitude to disaster nursing [J]. Chinese Nursing Research, 2011, 25 (33): 3028-3030. 